DOI: 10.4274/tod. galenos.2019.61587

Turk J Osteoporos 2019;25:93-8

\title{
Evaluation of Osteoporosis Awareness in Chronic Obstructive Pulmonary Disease Patients
}

\author{
Kronik Obstrüktif Akciğer Hastalığı Hastalarında Osteoporoz Farkındalığının \\ Değerlendirilmesi
}

(D) Onur Yazıcı, (D) Şule Taş Gülen, (D) Şenay Demir Yazıcı*

Aydın Adnan Menderes University Faculty of Medicine, Department of Chest Diseases, Aydın, Turkey

*Atatürk State Hospital, Clinic of Physical Medicine and Rehabilitation, Aydın, Turkey

\section{Abstract}

Objective: Osteoporosis is a significant health problem that affects the quality of life negatively and places a serious burden on the national economy. The risk of osteoporosis in chronic obstructive pulmonary disease (COPD) patients is increased compared to the normal population; however, the knowledge level of the COPD patients related to osteoporosis has not been clearly known. The aim of our study was to investigate the awareness and knowledge level of COPD patients about osteoporosis.

Materials and Methods: The patients diagnosed with COPD who admitted to the outpatient clinic of chest diseases between April 2018 and December 2018 were included in the study. The demographic data of the patients were recorded. Whether they have information about osteoporosis and if they know, the sources of information, whether they applied to a physician for this issue, and their knowledge level about the risk factors of osteoporosis were questioned and recorded.

Results: A total of 122 patients, of whom 111 were male, were included in the study. 54.9\% of the patients had knowledge about osteoporosis. It was found that they were informed mostly from people around them (28.7\%), physicians (23\%), and press (3.3\%). Even though more than half of the patients had known osteoporosis, only $6.6 \%$ knew that COPD was a risk factor, and $0.8 \%$ were informed by the chest physician about osteoporosis and referred to the relevant physician.

Conclusion: The knowledge level of COPD patients about osteoporosis was determined to be insufficient. All physicians, especially chest physicians, should give due consideration to this subject and education should be emphasized through the press.

Keywords: Osteoporosis, COPD, awareness

\section{Öz}

Amaç: Osteoporoz yaşam kalitesini olumsuz yönde etkileyen ve ülke ekonomisine ciddi yükler getiren önemli bir sağlık problemidir. Kronik obstrüktif akciğer hastalığı (KOAH) hastalarında osteoporoz riski normal popülasyona göre artmıştır ancak KOAH hastalarının osteoporozla ilgili bilgileri net olarak bilinmemektedir. Çalışmamızın amacı KOAH hastalarının osteoporoz hakkındaki farkındalığını ve bilgi düzeylerini araştırmaktır.

Gereç ve Yöntem: Çalışmaya Nisan 2018 - Aralık 2018 tarihleri arasında göğüs hastalıkları polikliniğe başvuran KOAH tanılı hastalar alındı. Hastaların demografik verileri kaydedildi. Osteoporoz hakkında bilgileri olup olmadığı, biliyorlarsa bilgi kaynakları, bunun için herhangi bir hekime gidip gitmedikleri ve osteoporozun risk faktörleri hakkındaki bilgileri sorgulanarak kaydedildi.

Bulgular: Çalışmaya 111 'i erkek toplam 122 hasta alındı. Hastaların \%54,9'nun kemik erimesi hakkında bilgisi vardı. Bilgiyi en çok çevreden $(\% 28,7)$, daha sonra ise doktordan $(\% 23)$ ve basından $(\% 3,3)$ aldığı tespit edildi. Hastaların yarısından fazlası kemik erimesini bilmesine rağmen sadece \%6,6'sı KOAH'nin bir risk faktörü olduğunu biliyordu ve \%0,8'i göğüs hastalıkları hekimi tarafından osteoporoz açısından bilgilendirilip ilgili hekime yönlendirilmişti.

Sonuç: KOAH hastalarının osteoporoz ile ilgili bilgi düzeylerinin yeterli olmadığı tespit edildi. Başta göğüs hastalıkları hekimi olmak üzere tüm hekimlerin konuya gereken önemi vermesi ve basın yayın aracılığı ile eğitimlere ağırlık verilmesi gerekmektedir.

Anahtar kelimeler: Osteoporoz, KOAH, farkındalık

Address for Correspondence/Yazıșma Adresi: Onur Yazıcı MD, Aydın Adnan Menderes University Faculty of Medicine, Department of Chest Diseases, Aydın, Turkey Phone: +90 2562155613 E-mail: dronur_yazici@hotmail.com ORCID ID: orcid.org/0000-0002-6272-4632 Received/Geliş Tarihi: 09.07.2019 Accepted/Kabul Tarihi: 16.09.2019

${ }^{\oplus}$ Copyright 2019 by the Turkish Osteoporosis Society

Turkish Journal of Osteoporosis published by Galenos Publishing House. 


\section{Introduction}

Chronic obstructive pulmonary disease (COPD) is a heterogeneous disorder characterized by persistent airway obstruction, having systemic effects, and associated with many comorbidities $(1,2)$. Osteoporosis is one of the comorbidities seen in COPD patients (3). The incidence of osteoporosis is increased in COPD patients due to causes such as systemic inflammation, oral and inhaled corticosteroid use, low body mass index, smoking, inactivity, and malnutrition (3-8). Conducted studies have shown that the incidence of osteoporosis increased 1.5-2-fold in COPD patients (9-12). Even though the incidence of osteoporosis is increased in COPD, most of these patients are not investigated and necessary treatment is not initiated $(13,14)$. Hip fractures which develop after osteoporosis disable mobilization of COPD patients, and vertebral compression fractures, by leading to kyphosis, cause reduction of pulmonary capacity in patients already with limited respiratory reserve and the symptoms being more prominent (15). This situation brings a serious burden to the economy of the country, together with increasing the morbidity and mortality rates of patients. When treatment costs for osteoporosis and subsequent fractures are considered, studies on prevention of the disease rather than its treatment have been gaining importance (16). Therefore, osteoporosis should be identified early, and various precautions should be taken for its prevention. The first of such measures is early identification of the risk groups and initiation of both the preventive and therapeutic management. The occurrence or progression of the disease can be prevented if the identified populations at risk are educated and necessary precautions are taken before bone loss develops. The awareness and knowledge level of the risk group should be identified for educational purposes. For this reason, in our study, we aimed to evaluate the knowledge level of COPD patients, who are individuals at risk for osteoporosis, about this disorder.

\section{Materials and Methods}

The study was designed as a prospective cross-sectional study and was approved by Aydın Adnan Menderes University Ethical Committee, Aydın, Turkey (no: 2018/1356). All participants signed informed consent forms. The patients who had presented to the Outpatient Clinics of Chest Diseases and who had been diagnosed with COPD according to the GOLD criteria (17) in Aydın Adnan Menderes University Medical Faculty between April 2018 and December 2018 were included in the study. The inclusion criteria were to be diagnosed with COPD for at least the last two years and to accept to participate in the study. The demographic data of the patients such as age, gender, height, body weight, educational status, and smoking history were recorded. It was questioned whether the patient had knowledge of osteoporosis, and if informed, what was its source, and in case the source was a physician, which physician the source was. It was also questioned whether the patient had presented to a physician due to osteoporosis, together with the conducted investigations. Regarding osteoporosis, risk factors such as aging, female gender, menopause, genetic factors, inadequate calcium intake, insufficient exposure to sunlight, lack of exercise, smoking, caffeine-containing beverages, and thyroid disorders were questioned and the knowledge of the patients on these was identified. Moreover, the patients were questioned for a history of balance problems, falls, and fractures.

\section{Statistical Analysis}

All statistical analyses were done using SPSS 17.0 for Windows (SPSS Inc., Chicago, IL, USA). Quantitative variables are expressed as mean \pm standard deviation, and qualitative variables are given as frequency and percentage. The relationship between the knowledge level and the educational level was evaluated by Kendall correlation analysis. $\mathrm{P}<0.05$ was considered significant.

\section{Results}

A total of 122 COPD patients with the mean age of $66.64 \pm 8.08$ years, of whom 111 (91\%) were male and 11 (9\%) were female, were included in the study. Of all patients, $12(9.8 \%)$ were stage 1, $68(55.7 \%)$ stage 2, $27(22.1 \%)$ stage 3, and 15 $(12.3 \%)$ stage 4 COPD patients. Eighty-seven (73\%) patients were ex-smokers whereas 28 (23\%) were currently smoking. Five $(4.1 \%)$ patients had no smoking history; however, these patients had a history of biomass exposure. The average annual cigarette consumption rate of the patients was $44.61 \pm 40.47$ packs. The demographic data of the patients were shown in Table 1.

When the patients were asked what the term of osteoporosis meant, 114 (93.7\%) patients expressed that they had not heard it before. When the question was asked again as what bone thinning was, 67 (54.9\%) patients expressed that they had heard about it previously whereas 55 (45.1\%) expressed that they had never heard about it. It was determined that the knowledge level increased with increasing educational level $(r=0.329, p<0.001)$. When the source of information was asked to the patients who were aware of osteoporosis, 35 (28.7\%) patients said that they had learned it from the people around them, 28 (23\%) patients from a physician, and 4 (3.3\%) patients from the press. Among the patients who said that they had learned from a physician, $21(17.2 \%)$ patients expressed the physician as the physical therapy and rehabilitation specialist, 6 (4.9\%) from the family physician, and only one patient $(0.8 \%)$ stated that the information source was a pulmonologist. Even though $54.9 \%$ of the patients were aware of osteoporosis and $23 \%$ of these patients had learned it from a physician, only 14 $(11.5 \%)$ patients had presented to a physician for investigation of the disorder.

When the knowledge level of the patients about the risk factors leading to osteoporosis was assessed, it was determined that 8 $(6.6 \%)$ patients knew that COPD was a risk factor whereas 18 $(14.8 \%)$ patients were aware of smoking as a risk factor, and $16(13.1 \%)$ patients knew that used drugs were risk factors. 
Table 1. The demographic data of the patients

\begin{tabular}{|c|c|}
\hline Age (years) & $66.64 \pm 8.08$ \\
\hline BMI $\left(\mathrm{kg} / \mathrm{m}^{2}\right)$ & $25.39 \pm 4.33$ \\
\hline $\begin{array}{l}\text { Gender } n(\%) \\
\text { Female } \\
\text { Male }\end{array}$ & $\begin{array}{l}11(9) \\
111(91)\end{array}$ \\
\hline $\begin{array}{l}\text { Occupation n (\%) } \\
\text { Housewife } \\
\text { Employee } \\
\text { Retired }\end{array}$ & $\begin{array}{l}3(2.5) \\
21(17.2) \\
98(80.3)\end{array}$ \\
\hline $\begin{array}{l}\text { Educational status n (\%) } \\
\text { Illiterate } \\
\text { Primary school } \\
\text { Middle school } \\
\text { High school } \\
\text { University }\end{array}$ & $\begin{array}{l}9(7.4) \\
85(69.6) \\
10(8.2) \\
9(7.4) \\
9(7.4)\end{array}$ \\
\hline $\begin{array}{l}\text { Place of residence } \mathrm{n}(\%) \\
\text { Urban area } \\
\text { Rural area }\end{array}$ & $\begin{array}{l}53(43.4) \\
69(56.6)\end{array}$ \\
\hline $\begin{array}{l}\text { History of osteoporosis in the family (spouse } \\
\text { or mother) } n(\%)\end{array}$ & $25(20.5)$ \\
\hline $\begin{array}{l}\text { Smoking status n (\%) } \\
\text { Non-smoker } \\
\text { Ex-smoker } \\
\text { Currently smoking }\end{array}$ & $\begin{array}{l}5(4.1) \\
89(72.9) \\
28(23)\end{array}$ \\
\hline Cigarette (pack-year) & $44.61 \pm 40.47$ \\
\hline $\begin{array}{l}\text { Stage n (\%) } \\
1 \\
2 \\
3 \\
4\end{array}$ & $\begin{array}{l}12(9.8) \\
68(55.7) \\
27(22.1) \\
15(12.3)\end{array}$ \\
\hline
\end{tabular}

Table 2. The knowledge level of the patients

\begin{tabular}{|l|l|l|l|}
\hline Risk factor & Yes n (\%) & No $\mathbf{n ~ ( \% ) ~}$ & $\begin{array}{l}\text { I don't } \\
\text { know } \mathbf{~} \\
\mathbf{( \% )}\end{array}$ \\
\hline Aging & $48(39.3)$ & $2(1.6)$ & $72(59)$ \\
\hline Female gender & $34(27.9)$ & $3(2.5)$ & $85(69.7)$ \\
\hline $\begin{array}{l}\text { Inadequate calcium } \\
\text { intake }\end{array}$ & $42(34.4)$ & $3(2.5)$ & $77(63.1)$ \\
\hline Menopause & $27(22.1)$ & $5(4.1)$ & $90(73.8)$ \\
\hline Lack of exercise & $31(25.4)$ & $6(4.9)$ & $85(69.7)$ \\
\hline Genetics & $12(9.8)$ & $13(10.7)$ & $97(79.5)$ \\
\hline $\begin{array}{l}\text { Insufficient exposure } \\
\text { to sunlight }\end{array}$ & $18(14.8)$ & $13(10.7)$ & $91(74.6)$ \\
\hline Caffeine (tea\&coffee) & $8(6.6)$ & $10(8.2)$ & $104(85.2)$ \\
\hline Smoking & $18(14.8)$ & $6(4.9)$ & $98(80.3)$ \\
\hline Drugs & $16(13.1)$ & $6(4.9)$ & $100(82)$ \\
\hline COPD disease & $8(6.6)$ & $6(4.9)$ & $108(88.5)$ \\
\hline Thyroid disease & $3(2.5)$ & $11(9)$ & $108(88.5)$ \\
\hline copD: Chronic obstructive pulmonary disease & & \\
\hline
\end{tabular}

The knowledge status of the patients regarding risk factors was given in Table 2. When the patients were asked whether they had used corticosteroids, which might have been posing a risk regarding osteoporosis, 28 (23\%) patients expressed that they had used corticosteroids whereas 94 (77\%) were not aware of whether they had used or not. When the drugs used by the patients were investigated through the healthcare recording system, it was determined that $26(21.3 \%)$ patients had used systemic corticosteroids in the last year, and 76 (62.3\%) patients were currently using inhaled corticosteroids. When the patients were asked whether they had information on corticosteroids, it was determined that 107 (87.7\%) patients did not have any relevant information. In our study, it was determined that 59 (48.4\%) patients had encountered imbalance, 36 (29.5\%) falls, and $11(9 \%)$ fractures. Of these fractures, six were related to the forearm, three to the hip, and two to the vertebra regions.

\section{Discussion}

Chronic diseases and their complications have increased with increasing life expectancy. Financial resources spent on such disorders have been increasing with each passing day. According to the health policies regarding chronic disorders, it is important to identify populations at risk and to take primary preventive measures (18). The most important primary preventive measure is education. The awareness and the knowledge level of the group at risk should be known to provide such education. Identification of more commonly used information sources will participate in informing the patients correctly by allocating more resources and time to those sections.

In the conducted studies about awareness of osteoporosis, the awareness rate varies between $44 \%$ and $89 \%$ (19-21). The reason for the discrepancies among the rates found in the studies is that the knowledge levels of the individuals are affected by numerous factors such as gender, educational background, and the place of inhabitance. For example, in the study conducted by Özişler et al. (22), a high awareness rate of $88 \%$ was found; however, when the participants of that study were considered, it was observed that the number of women was very high (women/men ratio was 5 ). In the conducted studies, the awareness of osteoporosis was found to be less in men when compared to women $(23,24)$. In our study, the rate of osteoporosis awareness was found as $54.9 \%$. Unlike other studies on awareness, the number of males was higher due to the increased presence of COPD in men. Studies on osteoporosis have usually been conducted by questioning female-weighted populations (22). We consider that one of the reasons for the lower awareness rate in our study had originated from the lower education level in our study population. Only 14.8\% of our patients had graduated from high school or university, and we determined that the rate of osteoporosis awareness increased with increasing educational level $(r=0.329, p<0.001)$. A direct relationship between educational status and awareness of osteoporosis was determined in other conducted studies also 
$(19,25)$.

When the sources of information related to osteoporosis were questioned, it was determined that $23 \%$ had heard from a physician, $28.7 \%$ from the people around them, and 3.3\% from the press. In the study conducted by Aksu et al. (19), the first-line information source was reported as the press. Juby and Davis (20) determined that the main information sources of their patients were television, printed press, and friends. In our study, the patients expressed that they had been mostly informed on osteoporosis by people around them. We think that our patients had been informed about osteoporosis due to the presence of osteoporosis history in either the spouse or the mother in $20.5 \%$ of the participants. Even though approximately half of our patients had heard of osteoporosis from a physician, from people around, or press, only $11.5 \%$ of these had presented to a physician for this issue. Since most of the patients were male, even though they had heard or known osteoporosis, they had not felt obliged to present to a physician, thinking that osteoporosis was a disease of women and they were not in the risk group. The delusion rate of osteoporosis as being perceived as a disorder concerning women only is high (22). Unlike the medical literature, in our study, only $3 \%$ of our patients expressed that they had been informed through press. We suggest that this originated from the press providing insufficient information on osteoporosis. Therefore, more space should be given to attention-grabbing news in the written and visual media for education of the people.

Providing patient education will increase the compliance of patients with treatment besides raising awareness about osteoporosis. In a conducted study, it was shown that the osteoporosis-related education provided by the physician to the osteoporotic patients increased the compliance of the patients with their treatment (26). This suggests that for compliance with treatment, not only education is enough, but also the source of information is important. In our study, only $0.8 \%$ of the patients had been informed on osteoporosis by a pulmonologist. Therefore, besides training about treatment of the primary disease, the pulmonologists should also be educated on raising patient awareness about osteoporosis, which has an increased likelihood of accompanying the disorder, together with their referral to a relevant physician.

In our study, $93.4 \%$ of the patients were not aware that COPD was a risk factor for osteoporosis. This suggests that in outpatient clinics, the primary disease and its treatment are focused on more, and probable comorbidities are not dealt with satisfactorily. In a study conducted in United Kingdom, it was found that practitioners had not been sufficiently informed about osteoporosis during their training (27).

Aging is an important risk factor for osteoporosis (28). COPD is a disorder that is met in patients over 40 years of age and has an increasing incidence with age (29). In our study, the mean age of the patients was 66.64 years, and it was determined that $60.6 \%$ of the patients had not known that aging was a risk factor for osteoporosis. In COPD patients, in addition to the disorder itself, administered steroids also increase the risk of osteoporosis. It has been recommended in a study that, whatever the initial bone density measurement scores of the patients are, dual energy x-ray absorptiometry should be conducted on a yearly basis in all COPD patients in whom oral corticosteroids are administered (30). In a study, bone density measurements were performed and treatment was initiated in only $48 \%$ of the patients using oral corticosteroids, and since the rest of the patients were not investigated, severe osteoporosis and related fractures were not able to be identified in advance (31). In our study also, 77\% of the patients were unaware of whether they had been using corticosteroids or not. When their records were evaluated, it was determined that $21.3 \%$ of them had used systemic corticosteroids in the last year, and $62.3 \%$ of them were currently using inhaled steroids; however, in only $11.5 \%$ of the patients, bone density measurements were performed. Moreover, $93.4 \%$ of the patients did not know that the drugs they had been using were risk factors for osteoporosis.

Smoking is one of the significant risk factors for osteoporosis. However, patients do not have enough information about this factor. In a study, it was determined that $27.6 \%$ of patients did not know that smoking was a risk factor for osteoporosis (32). In our study, $80.3 \%$ of the patients did not know that smoking was a risk factor and $23 \%$ were currently active smokers.

When risk factors for osteoporosis are taken into consideration in general, while awareness about age, female gender, inadequate calcium intake, and not to exercise as risk factors were partially more, awareness about thyroid disorders, drugs, and caffeine-containing beverages such as tea-coffee as risk factors were found significantly less.

Fractures occurring because of osteoporosis are significant causes of morbidity and mortality. Most commonly, hip fractures occur following osteoporosis, and since these are symptomatic, the patients are hospitalized; thus, the prevalence of hip fractures is more clearly known. Because most of the vertebral fractures are asymptomatic, its prevalence is not certainly known. In a study, the prevalence of vertebral fractures was reported to be $72 \%$ higher in COPD patients compared to the control group (33). In our study, 11 patients had a history of fracture. Of these, six were forearm, three were hip, and two were vertebral fractures. Since vertebral fractures may be asymptomatic, we think that the actual number of fractures might have been more. Once a vertebral fracture develops, the occurrence risk of fractures in other vertebrae increases, and eventually, asymptomatic fractures become symptomatic with developing pain, impairing the quality of life of the patient. Additionally, vertebral fractures cause a reduction in vital capacity, leading to an increase in symptoms of COPD patients with limited respiratory reserve. In a published study, it was reported that each vertebral fracture had led to a $9 \%$ reduction in vital capacity (34).

Since osteoporosis is an important disorder that might cause fractures, probable complications can be avoided by taking 
preventive and therapeutic measures like identification of risk groups such as COPD, providing information to those patients, and directing them to relevant physicians (19).

\section{Conclusion}

It was determined that even though the risk of osteoporosis was increased in COPD patients, they did not have enough information about this subject. The patients were found to be informed mostly by the people around them, followed by the physicians. However, it was realized that the chest physicians had not sufficiently informed their patients and had not referred them to the relevant physicians. It was also detected that the patients had not received enough information through press. Therefore, we think that more space should be given to attention-grabbing news in the written and visual media for informing COPD patients about osteoporosis, and all relevant physicians, mainly the pulmonologists, should give the necessary attention to this subject.

\section{Ethics}

Ethics Committee Approval: The study was designed as a prospective cross-sectional study and was approved by Aydın Adnan Menderes University Ethical Committee, Aydın, Turkey (no: 2018/1356).

Informed Consent: All participants signed informed consent forms.

Peer-review: Externally and internally peer-reviewed.

\section{Authorship Contributions}

Surgical and Medical Practices: O.Y., Ş.T.G., Concept: O.Y., Ş.D.Y., Design: O.Y., Ş.T.G., Data Collection or Processing: O.Y., Ş.D.Y., Analysis or Interpretation: O.Y., Ş.D.Y., Literature Search: O.Y., Ş.T.G., Ş.D.Y., Writing: O.Y., Ş.T.G, Ş.D.Y.

Conflict of Interest: No conflict of interest was declared by the authors.

Financial Disclosure: The authors declared that this study received no financial support.

\section{References}

1. Global Strategy for the Diagnosis, Management and Prevention of COPD, Global Initiative for Chronic Obstructive Lung Disease (GOLD) 2017.

2. Okutan O, Ayten Ö. Kronik obstrüktif akciğer hastalığı ve komorbiditeler. Solunum 2012;14:182-3.

3. Romme EA, Smeenk FW, Rutten EP, Wouters EF. Osteoporosis in chronic obstructive pulmonary disease. Expert Rev Respir Med 2013;7:397-410.

4. Sarkar M, Bhardwaj R, Madabhavi I, Khatana J. Osteoporosis in chronic obstructive pulmonary disease. Clin Med Insights Circ Respir Pulm Med 2015;9:5-21.

5. Decramer M, Janssens W, Miravitlles M. Chronic obstructive pulmonary disease. Lancet 2012;379:1341-51.

6. Graat-Verboom L, Wouters EF, Smeenk FW, van den Borne BE, Lunde R, Spruit MA. Current status of research on osteoporosis in COPD: a systematic review. Eur Respir J 2009;34:209-18.

7. Lehouck A, Boonen S, Decramer M, Janssens W. COPD, bone metabolism, and osteoporosis. Chest 2011;139:648-57.

8. Ward KD, Klesges RC. A meta-analysis of the effects of cigarette smoking on bone mineral density. Calcif Tissue Int 2001;68:259-70.
9. Bolton $C E$, Ionescu AA, Shiels KM, Pettit RJ, Edwards PH, Stone $M D$, et al. Associated loss of fat-free mass and bone mineral density in chronic obstructive pulmonary disease. Am J Respir Crit Care Med 2004;170:1286-93.

10. Sabit R, Bolton CE, Edwards PH, Pettit RJ, Evans WD, McEniery $\mathrm{CM}$, et al. Arterial stiffness and osteoporosis in chronic obstructive pulmonary disease. Am J Respir Crit Care Med 2007;175:1259-65.

11. Dam TT, Harrison S, Fink HA, Ramsdell J, Barrett-Connor $E$, Osteoporotic Fractures in Men Research G. Bone mineral density and fractures in older men with chronic obstructive pulmonary disease or asthma. Osteoporos Int 2010;21:1341-9.

12. Chen SJ, Liao WC, Huang KH, Lin CL, Tsai WC, Kung PT, et al. Chronic obstructive pulmonary disease and allied conditions is a strong independent risk factor for osteoporosis and pathologic fractures: a population-based cohort study. QJM 2015;108:63340.

13. Graat-Verboom L, Spruit MA, van den Borne BE, Smeenk FW, Martens EJ, Lunde R, et al. Correlates of osteoporosis in chronic obstructive pulmonary disease: An underestimated systemic component. Respir Med 2009;103:1143-51.

14. Majumdar SR, Villa-Roel C, Lyons KJ, Rowe BH. Prevalence and predictors of vertebral fracture in patients with chronic obstructive pulmonary disease. Respir Med 2010;104:260-6.

15. Carter JD, Patel S, Sultan FL, Thompson ZJ, Margaux H, Sterrett $A$, et al. The recognition and treatment of vertebral fractures in males with chronic obstructive pulmonary disease. Respir Med 2008;102:1165-72.

16. Torgerson DJ, Campbell MK, Reid DM. Life-style, environmental and medical factors influencing peak bone mass in women. $\mathrm{Br} J$ Rheumatol 1995;34:620-4.

17. Vestbo J, Hurd SS, Agusti AG, Jones PW, Vogelmeier C, Anzueto $A$, et al. Global strategy for the diagnosis, management, and prevention of chronic obstructive pulmonary disease: GOLD executive summary. Am J Respir Crit Care Med 2013;187:347-65.

18. Karapolat H, Eyigör S, Gürgün G, Kirazlı Y, Başoğlu ÖK, Durmaz B. Erkek KOAH Hastalarında Osteoporozun Değerlendirilmesi. Osteoporoz Dünyasından 2007;13:70-4.

19. Aksu A, Zinnuroğlu $M$, Karaoğlan B, Akın S, Gökçe-Kutsal $Y$, Atalay F, et al. Osteoporoz, Eğitim Durumu ve Farkındalık Düzeyi Araştırma Sonuçları. Osteoporoz Dünyasından 2005;11:36-40.

20. Juby $A G$, Davis $P$. A prospective evaluation of the awareness, knowledge, risk factors and current treatment of osteoporosis in a cohort of elderly subjects. Osteoporos Int 2001;12:617-22.

21. Kutsal YG, Atalay A, Arslan S, Başaran A, Cantürk F, Cindaş $A$, et al. Awareness of osteoporotic patients. Osteoporos Int 2005;16:128-33.

22. Özişler Z, Delialioğlu SÜ, Özel S, Onat ŞS, Şahin AY, Dolmuş M. Yaşılıarda Osteoporoz Farkındalığı: Yaşlılarımız Nerede? . Türk Osteoporoz Dergisi. 2015;21:69-72.

23. Ní Chróinín D, Glavin P, Power D. Awareness of osteoporosis, risk and protective factors and own diagnostic status: a cross-sectional study. Arch Osteoporos 2013;8:117.

24. Sinclair HK, Bond CM, Taylor RJ. Hormone replacement therapy: a study of women's knowledge and attitudes. Br J Gen Pract 1993;43:365-70.

25. Magnus JH, Joakimsen RM, Berntsen GK, Tollan A, Søogaard AJ. What do Norwegian women and men know about osteoporosis? Osteoporos Int 1996;6:32-6.

26. Aghamirsalim M, Mehrpour SR, Kamrani RS, Sorbi R. Effectiveness of educational intervention on undermanagement of osteoporosis in fragility fractures. Arch Orthop Trauma Surg 2012;132:1461-5.

27. Taylor JC, Sterkel B, Utley M, Shipley M, Newman S, Horton $M$, et al. Opinions and experiences in general practice on osteoporosis prevention, diagnosis and management. Osteoporos Int 2001;12:844-8.

28. Gökçe-Kutsal Y. Yaşlılarda osteoporoz. Türkiye Klinikleri. 2012;5:79-85

29. Lindberg A, Jonsson AC, Rönmark $E$, Lundgren R, Larsson LG, Lundbäck B. Ten-year cumulative incidence of COPD and risk factors for incident disease in a symptomatic cohort. Chest 2005; 127:1544-52.

30. Jørgensen NR, Schwarz P. Osteoporosis in chronic obstructive pulmonary disease patients. Curr Opin Pulm Med 2008;14:122-7. 
31. Nielsen BR, Jørgensen NR, Schwarz P. Management of risk of glucocorticoid-induced osteoporosis due to systemic administration in general practice in Denmark. Eur J Gen Pract 2007;13:168-71.

32. Yeap SS, Goh EM, Das Gupta E. Knowledge about osteoporosis in a Malaysian population. Asia Pac J Public Health 2010;22:233-41.

33. Kjensli A, Falch JA, Ryg M, Blenk T, Armbrecht G, Diep LM, et al. High prevalence of vertebral deformities in COPD patients: relationship to disease severity. Eur Respir J 2009;33:1018-24.

34. Harrison RA, Siminoski K, Vethanayagam D, Majumdar SR. Osteoporosis-related kyphosis and impairments in pulmonary function: a systematic review. J Bone Miner Res 2007;22:447-57. 